\title{
The vertical distribution of zooplankton in stratified mesotrophic Lake Arakhley (Eastern Transbaikalia)
}

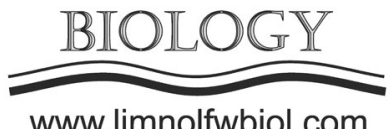

www.limnolfwbiol.com

\author{
Itigilova M.Ts. * \\ Institute of Natural Resources, Ecology and Cryology Siberian Branch of the Russian Academy Sciences, \\ Nedorezov Str., 16-a, 672014 Chita, Russia
}

\begin{abstract}
We have studied the vertical distribution of zooplankton of a stratified mesotrophic lake. Thus, in August 2011 and 2013, copepods dominated the composition of the zooplankton of the mesotrophic Lake Arakhley and had a density maximum either in the upper euphotic layer or in the area of the metalimnion, with a gradual decrease in the lower layers of water. By 2013, the zooplankton community changed and mainly consisted of cladocerans, and they both dominated in numbers.
\end{abstract}

Keywords: zooplankton, species composition, vertical distribution, temperature, Lake Arakhley, East Transbaikalia

\section{Introduction}

The zooplankton community is a complex and multicomponent system determined by many factors. The change in its species composition, quantitative and qualitative parameters with the depth of the water body as well as the factors that determine them are of great theoretical and practical interest. In recent decades, climate warming has been observed, which affects various processes occurring in aquatic ecosystems, including zooplankton communities. In Transbaikalia, air temperature increases by $1.0-1.5{ }^{\circ} \mathrm{C}$ in winter and by $0.5-1.0{ }^{\circ} \mathrm{C}$ in summer (Vezhnovets et al., 2012; Feniova et al., 2016). The increase in the surface water temperature by $1.21{ }^{\circ} \mathrm{C}$ was recorded in Lake Baikal (Moore et al., 2009). The 2011 and 2013 years of the study are from the arid climatic period.

The lake during these years, despite the large area of $59.0 \mathrm{~km}^{2}$ and the water volume of $0.60 \mathrm{~km}^{3}$, had an average depth of $10.2 \mathrm{~m}$ and a maximum depth of $17.0 \mathrm{~m}$. The transition between the low-water and high-water years is 2017. Temperature, dissolved oxygen concentration, food resources, etc. have a significant effect on the distribution of zooplankton organisms. At the same time, temperature and oxygen are the most important factors in the regulation of zooplankton communities, as well as its spatial and temporal scale of lake ecosystems, since they affect the abundance and structure of zooplankton communities. In this regard, the impact of climate warming reflected in the increase in water temperature on the vertical structure of zooplankton and on subsequent changes in the ecosystem arises the question.

\section{Materials and methods of research}

Zooplankton studies were performed in the mesotrophic Lake Arakhley (52 ${ }^{\circ} 12^{\prime} 20$ "N, lat. $112^{\circ}$ 52 '01" E) during the period of thermal stratification of the lake in August from 2011 and 2013. The sampling of zooplankton was carried out at the central station of the lake using a Patalas bathometer (volume 61 ) with triplicate from eight vertical layers every two meters of the water column. Samples were fixed with $4 \%$ formalin. Quantitative processing of the collected material performed in the Kolkwitz and Bogorov chambers. Organisms were calculated and measured on LOMO Micmed-1, MBS-10 microscopes. Animals were determined on Nikon Eclipse E200 and AXIO SCOPE A1 microscopes. Quantification was performed based on generally accepted methods. The species composition of zooplankton was determined by the corresponding determinants. The temperature of the water was measured with a mercury thermometer embedded in the bathometer. At the same time, the temperature was considered together with the sampling of the zooplankton along the horizons of the water column $0,2,4,6,8,10,12$, and $14 \mathrm{~m}$. The water transparency values for the Secchi disk for these years ranged from 4.5 to $6.4 \mathrm{~m}$. Quantitative accounting of the number was carried out on the basis of generally accepted methods (Guidelines ..., 1983). The species composition of zooplankton was determined by the corresponding determinants (Manuylova, 1964; Kutikova, 1970; Borutsky et al., 1991). 


\section{Results and discussion}

Tables 1 and 2 show the species composition, number and relevance of each species to the selected horizons. In these tables, among all years studied we discuss 2011 and 2013 due to the fact that they have the most distinctive features in the distribution of zooplankton and the number of species. Thus, the dry 2013 showed rotifers of the genera Brachionus and Synchaeta, which were not previously observed. The number of individual species and the ratio of taxonomic groups in the vertical layers of water in August 2011 and 2013 significantly differed at the level of identical species composition.

The number of zooplankton in the surface layer of water in 2011 was small (2.6 thousand indiv. $/ \mathrm{m}^{3}$ ) and consisted mainly of nauplial copepodite stages of diaptomus, cyclops and rotifers. The maximum number of zooplankton $\left(76.2\right.$ thousand indiv. $/ \mathrm{m}^{3}$ ) was observed in the epilimnion at a four-meter depth with $79 \%$ dominance of the copepods, mainly $E$. graciloides. The number of zooplankton in the metalimnion (at a depth of $10 \mathrm{~m}$ ) was 38.19 thousand indiv. $/ \mathrm{m}^{3}$. Cladocerans D. galeata represented $60 \%$ of the total number. In the hypolimnion, $52 \%$ of the animals were rotifers $-K$. longispina and A. priodonta. Unlike crustaceans, rotifers in August were not the dominant zooplankton group in the epilimnion. Notably, there was a very significant increase in their share at the lower boundary of the metalimnion and in the hypolimnion. Thus, in 2011, different species dominated in number in different vertical layers of water (Table 1 ).

In 2013, the temperature rise in the surface layers of water reached up to $22{ }^{\circ} \mathrm{C}$. Under these conditions, zooplankton animals were distributed over the vertical layers of the water column more or less evenly. The maximum number was observed in the water layer from two to eight meters (up to 69.48 thousand indiv./ $\mathrm{m}^{3}$ ). Unlike 2011, in 2013, the crustacean $D$. galeata (thermophilic species presented in summer hypolimnion (Stolbunova, 2006; Rivier, 2012)) dominated all layers, and the situation differed fundamentally in Lake Arakhley: the largest proportion of Cladocera (81\%) was in the uppermost oxygenated epilimnion layer at a temperature of $20.0-21.9^{\circ} \mathrm{C}$, in metalimnion, with a decrease in temperature to $19.8{ }^{\circ} \mathrm{C}, D$. galeata also dominated, but was $62 \%$ of the total number of zooplankton. As the depth in the hypolimnion increased (at a temperature of $10.0{ }^{\circ} \mathrm{C}$ ), the relative abundance of D. galeata continued to decrease, reaching $52 \%$ in the bottom layer of water. This year, there was a change in the percentage of taxonomic groups due to an increase in the proportion of cladocerans and rotifers in the total number and a decrease in the share of copepods.

The dominant species of zooplankton in different years are presented in Table 3 .

Thus, in 2011 D. galeata and E. graciloides were $22-24 \%$, and in 2013 D. galeata was $65 \%$ of the total number of zooplankton.

Therefore, an increase in temperature can cause a change in the vertical structure of zooplankton and even in the dominant species. The vertical distribution of zooplankton communities in stratified lakes during summer is due to temperature, the abundance of food and the presence of oxygen. These factors affecting the state of the ecosystem regulate the structure and abundance of zooplankton communities. While in August 2011 the surface temperature of water ranged from 18 to $19{ }^{\circ} \mathrm{C}$, in 2013 water temperature rose to $21.9{ }^{\circ} \mathrm{C}$. We determined that with increasing water temperature there was a change in the percentage of taxonomic groups of zooplankton towards an increase in the proportion of cladocerans and a decrease in the share of copepods. Hence, an increase in the water temperature in low-water and high-water years affects the dominant zooplankton complex in different ways. Thus, with an increase in water temperature in the low-water period, cladocerans and rotifers dominate the zooplankton community, and in the high-water period - copepods (Table 2).

In the vertical distribution of zooplankton over the studied years, the identified features of the species composition, abundance of zooplankton show that in August 2011 copepods E. graciloides dominated at a water temperature of $18-19{ }^{\circ} \mathrm{C}$, comprising $16-56$ $\%$ in the upper layers $(0-2 \mathrm{~m}), 73-75 \%$ at a depth of 4-6 $\mathrm{m}$, and $49-37 \%$ in metalimnion $(8-10 \mathrm{~m})$. In the hypolimnion (12-14 $\mathrm{m}$ ), the number of organisms was $26-29 \%$ of the number of zooplankton. Therefore, copepods $E$. graciloides were the most dominant at a depth of 4-6 m.

With a further increase in the water temperature to $21.9{ }^{\circ} \mathrm{C}$ in August 2013, cladocerans, mainly $D$. galeata, dominated the zooplankton community, accounting for $70-80 \%$ in the upper water horizons $(0-6 \mathrm{~m})$ with a decrease to $50-67 \%$ in the number of zooplankton in the corresponding layer of water in the horizons of 8-14 m. In 2013, the zooplankton community differed from the previous years. There were changes in the percentage of taxonomic groups towards an increase in the proportion of cladocerans in the total number of zooplankton and a decrease in the proportion of copepods.

We have obtained a vertical distribution of structural changes in zooplankton communities associated with the transformation of the temperature factor over the horizontal layers of the water column (species composition, abundance of zooplankton).

\section{Conclusions}

1. We studied the effect of water temperature on the vertical distribution of zooplankton in a stratified mesotrophic lake on the example of Lake Arakhley in the low-water period (when the water level of the lake was $0.35-0.43 \mathrm{~m}$ ).

2. We revealed that the surface layer of water in August 2011 warmed up to a temperature of $18.1-19.3^{\circ} \mathrm{C}$, and in the warmest 2013 the temperature reached $21.9{ }^{\circ} \mathrm{C}$.

3. We found that copepods dominated the zooplankton community in 2011, whereas cladocerans dominated in warm 2013. 
Table 1. Species composition and abundance (thousand indiv. $/ \mathrm{m}^{3}$ ) of zooplankton in the water column of Lake Arakhley in August 2011

\begin{tabular}{|c|c|c|c|c|c|c|c|c|}
\hline \multirow{2}{*}{ Species } & \multicolumn{8}{|c|}{ Depth, m } \\
\hline & 0 & 2 & 4 & 6 & 8 & 10 & 12 & 14 \\
\hline \multicolumn{9}{|l|}{ Cladocera, Crustacea } \\
\hline $\begin{array}{l}\text { Daphnia galeata } \\
\text { Sars }\end{array}$ & 0.06 & 1.56 & 14.76 & 11.34 & 13.08 & 19.56 & 3.54 & 2.76 \\
\hline Ceriodaphnia pulchella Sars & 0 & 0 & 0.18 & 0 & 0.12 & 0 & 0 & 0 \\
\hline Bosmina longirostris (O.F.Muller) & 0.06 & 0 & 0 & 0 & 0.33 & 0 & 2.28 & 2.28 \\
\hline Leptodora kindtii (Focke) & 0 & 0.06 & 0.24 & 0.30 & 0.24 & 0 & 0.06 & 0 \\
\hline Bythotrephes longimanus Leydig & 0 & 0 & 0.06 & 0 & 0.06 & 0 & 0.06 & 0 \\
\hline Alona rectangula Sars & 0.06 & 0 & 0 & 0 & 0 & 0 & 0 & 0 \\
\hline Acroperus harpae Baird & 0 & 0 & 0 & 0.06 & 0 & 0 & 0 & 0 \\
\hline Total Cladocera & 0.18 & 1.62 & 15.24 & 11.76 & 13.83 & 19.56 & 5.88 & 5.04 \\
\hline \multicolumn{9}{|l|}{ Copepoda, Crustacea } \\
\hline naplii & 1.02 & 3.90 & 0.66 & 0.36 & 0.18 & 0 & 0.12 & 0 \\
\hline copepodit & 0.42 & 2.64 & 1.44 & 0.45 & 2.04 & 2.34 & 1.80 & 1.86 \\
\hline $\begin{array}{l}\text { Mesocyclops leuckarti } \\
\text { Thermocyclops crassus (Fisher) }\end{array}$ & 0 & 0.54 & 0.06 & 0.06 & 0.78 & 1.47 & 0.18 & 0.15 \\
\hline \multicolumn{9}{|l|}{ Eudiaptomus graciloides (Lilljeborg) } \\
\hline naplii & 0.36 & 4.44 & 1.02 & 0.72 & 0.36 & 0.06 & 0.78 & 0.12 \\
\hline copepodit & 0.06 & 1.86 & 3.62 & 0.24 & 1.14 & 0.36 & 0.24 & 0.60 \\
\hline adults & 0 & 9.00 & 53.10 & 30.84 & 17.60 & 13.26 & 8.46 & 8.76 \\
\hline Total Copepoda & 1.98 & 22.38 & 60.24 & 32.67 & 22.08 & 17.49 & 11.76 & 11.64 \\
\hline \multicolumn{9}{|l|}{ Rotifera } \\
\hline Asplanchna priodonta Gosse & 0.06 & 0.12 & 0.12 & 0 & 0.24 & 0.18 & 7.92 & 3.18 \\
\hline Kellicottia longispina (Kellicott) & 0 & 0 & 0.06 & 0.06 & 2.16 & 0.9 & 10.5 & 11.88 \\
\hline Keratella cochlearis (Gosse) & 0 & 0.06 & 0 & 0 & 0 & 0 & 0 & 0 \\
\hline Euchlanis dilatata Ehrenberg & 0.30 & 0.06 & 0.06 & 0 & 0 & 0 & 0 & 0 \\
\hline Conochilus unicornis Rousselet & 0.06 & 0.66 & 0.33 & 0 & 0 & 0 & 0 & 0 \\
\hline Polyarthra vulgaris Carlin & 0 & 1.65 & 0 & 0 & 0 & 0 & 0 & 0 \\
\hline Pompholyx sulcata Hudson & 0 & 0.18 & 0.18 & 0 & 0.18 & 0 & 0.12 & 0.06 \\
\hline Trichocerca multicrinis (Kellicott ) & 0 & 0.30 & 0 & 0 & 0.36 & 0.06 & 0 & 0.06 \\
\hline Filinia longiseta (Ehrenberg) & 0 & 0 & 0 & 0 & 0 & 0 & 0.24 & 0.66 \\
\hline Total Rotifera & 0.42 & 3.03 & 0.75 & 0.06 & 2.94 & 1.14 & 18.78 & 15.96 \\
\hline Total & 2.58 & 27.30 & 76.23 & 44.49 & 38.85 & 38.19 & 36.42 & 32.64 \\
\hline
\end{tabular}

Note: 0 - the species is absent. 
Table 2. Species composition and abundance (thousand indiv. $/ \mathrm{m}^{3}$ ) of zooplankton in the water column of Lake Arakhley in August 2013

\begin{tabular}{|c|c|c|c|c|c|c|c|c|}
\hline \multirow{2}{*}{ Species } & \multicolumn{8}{|c|}{ Depth, m } \\
\hline & 0 & 2 & 4 & 6 & 8 & 10 & 12 & 14 \\
\hline \multicolumn{9}{|l|}{ Cladocera, Crustacea } \\
\hline $\begin{array}{l}\text { Daphnia galeata } \\
\text { Sars }\end{array}$ & 32.52 & 55.74 & 33.46 & 24.96 & 34.02 & 34.98 & 37.38 & 19.92 \\
\hline Ceriodaphnia pulchella Sars & 0 & 0 & 0 & 0 & 1.32 & 0.18 & 0 & 0 \\
\hline Bosmina longirostris (O.F.Muller) & 3.12 & 1.92 & 1.62 & 1.44 & 4.56 & 4.32 & 1.74 & 1.98 \\
\hline Leptodora kindtii (Focke) & 0 & 0 & 0.06 & 0 & 0.36 & 0.12 & 0.06 & 0 \\
\hline Bythotrephes longimanus Leydig & 0 & 0 & 0.06 & 0 & 0 & 0 & 0 & 0 \\
\hline Chydorus sphaericus (O.F. Muller) & 1.08 & 0.12 & 0 & 0 & 0 & 0 & 0 & 0 \\
\hline Total Cladocera & 36.72 & 57.78 & 35.20 & 26.40 & 40.26 & 39.66 & 39.18 & 21.90 \\
\hline \multicolumn{9}{|l|}{ Copepoda, Crustacea } \\
\hline naplii & 1.74 & 2.04 & 1.98 & 1.74 & 11.76 & 4.02 & 1.80 & 1.80 \\
\hline copepodit & 1.50 & 2.46 & 1.20 & 1.32 & 6.12 & 5.06 & 5.64 & 8.40 \\
\hline Mesocyclops arachlensis Alekseev & 0.12 & 1.86 & 1.38 & 2.04 & 1.56 & 0.42 & 1.44 & 0.84 \\
\hline Thermocyclops crassus (Fisher) & 0.42 & 0 & 0 & 0.06 & 0.12 & 0.36 & 5.82 & 2.70 \\
\hline Macrocyclops albidus (Jurine) & 0.06 & 0 & 0 & 0 & 0 & 0.12 & 0.12 & 0 \\
\hline \multicolumn{9}{|l|}{ Eudiaptomus graciloides (Lilljeborg) } \\
\hline naplii & 0.96 & 0.90 & 0.90 & 0.36 & 5.10 & 2.16 & 0.12 & 0.54 \\
\hline copepodit & 0 & 0 & 0 & 0 & 0 & 0 & 0 & 0.06 \\
\hline adults & 0 & 0 & 0 & 0 & 0 & 0 & 0 & 0.06 \\
\hline Total Copepoda & 4.80 & 7.38 & 6.18 & 5.85 & 24.72 & 12.14 & 14.94 & 14.4 \\
\hline \multicolumn{9}{|l|}{ Rotifera } \\
\hline Asplanchna priodonta Gosse & 0.18 & 0.12 & 0.18 & 0.06 & 0.24 & 0.48 & 0.54 & 0.06 \\
\hline Kellicottia longispina (Kellicott) & 0.60 & 0.66 & 0.60 & 0 & 0.54 & 0.84 & 0.24 & 0.48 \\
\hline Keratella cochlearis (Gosse) & 0.90 & 0.36 & 0.30 & 0.24 & 0.78 & 0 & 0.18 & 0.18 \\
\hline K.quadrata (Muller) & 0.06 & 0 & 0.18 & 0 & 0.12 & 0.18 & 0 & 0.12 \\
\hline Euchlanis dilatata Ehrenberg & 0 & 0 & 0 & 0 & 0 & 0.54 & 0 & 0 \\
\hline Conochilus unicornis Rousselet & 0.06 & 0.06 & 0.12 & 0 & 0 & 0 & 0 & 0 \\
\hline Polyarthra vulgaris Carlin & 0.24 & 0.18 & 0 & 0.33 & 0.24 & 0.12 & 0.12 & 0.54 \\
\hline Pompholyx sulcata Hudson & 0 & 0 & 0 & 0 & 0.06 & 0.30 & 0 & 0.18 \\
\hline Trichocerca multicrinis (Kellicott) & 2.10 & 2.94 & 1.92 & 2.16 & 1.14 & 1.50 & 0.18 & 0.12 \\
\hline Filinia longiseta (Ehrenberg) & 0.06 & 0 & 0 & 0.06 & 0 & 0.06 & 0.18 & 0.9 \\
\hline Synchaeta sp. & 0 & 0 & 0 & 0 & 0.18 & 0 & 0 & 0 \\
\hline Brachionus sp. & 0.12 & 0.06 & 0 & 0 & 0 & 0 & 0 & 0.06 \\
\hline Total Rotifera & 4.32 & 4.32 & 3.24 & 2.97 & 3.30 & 4.02 & 1.44 & 2.70 \\
\hline Total & 45.84 & 69.48 & 44.62 & 35.22 & 68.28 & 55.82 & 55.56 & 39.10 \\
\hline
\end{tabular}


Table 3. The dominant zooplankton complex of Lake Arakhley in 2011 and 2013

\begin{tabular}{|c|c|c|c|}
\hline 2011 & \% of the total abundance & 2013 & \% of the total abundance \\
\hline Eudiaptomus graciloides & 22 & Daphnia galeata & 65 \\
Daphnia galeata & 24 & Eudiaptomus graciloides & 22 \\
Kellicottia longispina & 9 & Trichocerca multicrinis & 3 \\
\hline
\end{tabular}

\section{References}

Borutsky E.V., Stepanova L.A., Kos M.S. 1991. Key to freshwater Calanoida of the USSR. Saint-Petersburg: Nauka. (In Russian)

Feniova I.Yu., Razlutsky V.I., Palash A.L., Tunovsky Y., Zilitinkevich N.S. 2016. Vertical distribution of plankton crustaceans in meso-eutrophic lakes with different thermal regimes. Zoologichesky Zhurnal [Zoological Journal] 95: 153-166. (In Russian)

Guidelines for the collection and processing of materials for hydrobiological studies on freshwater bodies. Zooplankton and its products. 1983. In: Vinberg G.G., Lavrent'eva G.M. (Eds.). Leningrad: GosNIORH. (In Russian)

Kutikova L.A. 1970. Rotatoria of the USSR fauna. Identification guide. Leningrad: Nauka. (In Russian)
Manuylova E.F. 1964. Crustaceans (Cladocera) of the USSR fauna. Moscow-Leningrad: Science. (In Russian)

Moore M.V., Hampton S.E., Izmest'eva L.V., Silow E.A., Peshkova E.V., Pavlov B.K. 2009. Climate change and the world's "sacred sea" - Lake Baikal, Siberia. BioScience 59: 405-417.

Rivier I.K. 2012. Psychrophilic zooplankton of the lakes of the Upper Volga basin. Izhevsk: I.P. Permyakov. (in Russian)

Stolbunova V.N. 2006. Zooplankton of Lake Plescheevo. Moscow: Nauka. (in Russian)

Vezhnovets V.V. 2012. Features of the vertical distribution of zooplankton in dimictic lakes. In: International SchoolConference "Actual Problems of Studying of Continental Crustaceans”, pp. 153-155. (In Russian) 